
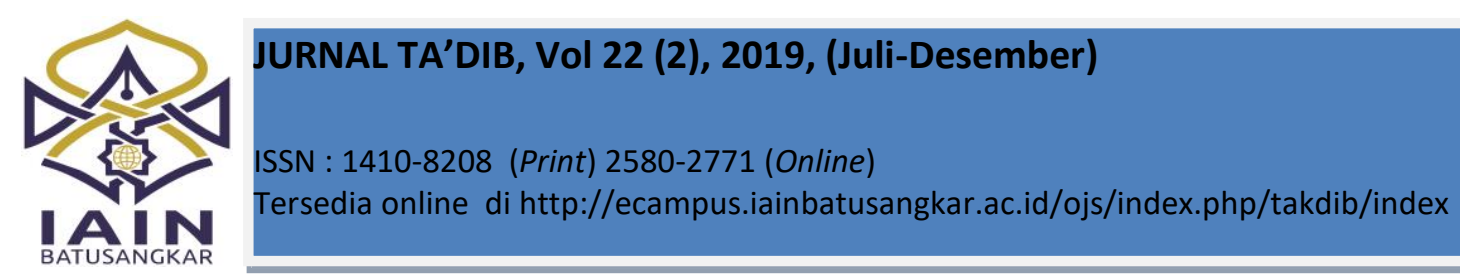

\title{
Pengaruh Metode Example Non Example terhadap Kompetensi IPA Peserta Didik pada Materi Interaksi Makhluk Hidup
}

\section{Lufri}

Universitas Negeri Padang

E-mail: lufri_unp@yahoo.com

\section{Amrianto*)}

Universitas Negeri Padang

E-mail: $\underline{\text { amrianto20@gmail.com }}$

\author{
Azwir Anhar \\ Universitas Negeri Padang \\ E-mail: anharazwir@yahoo.com
}

*) Corresponding Author

\begin{abstract}
Preliminarily, it was found that there are some problems faced by teachers in teaching and learning process. The problems are the teachers still implement classical rather than cooperative learning. Moreover, it is hard for them to make students active in the classroom, especially in asking questions and delivering ideas or opinions. Furthermore, it is also hard for them to develop students' curiosity in learning process. To overcome these problems, one solution which can be used is implementation of example non example method. The purpose of the research was to know the effect of example non example method on students' competence. It was a quasi experimental research. It was done in SMPN 18 Padang to VII grade students. Purposive sampling technique was used to take samples. The data were obteined through observation sheets for psychomotor competence. The technique of data analysis used Mann-Whitney $U$-Test in assistance of SPSS software. The findings show that the example non example method has significant effect on students' psychomotor competence.
\end{abstract}

Keywords: Example Non Example method, Competence, Motoric Skills

\section{PENDAHULUAN}

$\mathrm{K}$ urikulum 2013 menuntut adanya penyempurnaan dari beberapa pola dalam pembelajaran yang salah satunya yaitu dari pola pembelajaran pasif menjadi pembelajaran aktif (Kemendikbud, 2013). Pada tahun pelajaran 2017/2018, di Kota Padang 60 (63\%) dari 95 SMP baik negeri maupun swasta telah melaksanakan kurikulum 2013 dan selebihnya masih menerapkan kurikulum KTSP (Kemendikbud, 2018).

Peneliti melakukan penelitian pendahuluan di SMP Negeri 18 Padang pada bulan Agustus 2018, karena telah melaksanakan kurikulum 2013. Dengan tujuan mengidentifikasi masalah yang dihadapi di sekolah dengan menyebarkan angket. Peneliti memberikan angket pembelajaran kepada salah satu Tim Guru IPA SMP Negeri 18 Padang yaitu dengan
Deswita, beliau mengajar di kelas VII pada tahun pelajaran 2018/2019.

Hasil angket pembelajaran menunjukkan bahwa guru telah mampu untuk merancang perangkat pembelajaran sesuai dengan ketentuan kurikulum 2013. Namun dari segi pelaksanaan belum berjalan maksimal, karena masih terdapat permasalahan yang dihadapi guru khususnya dalam pembelajaran di kelas guru belum menerapkan pola belajar kelompok. Sangat sulit bagi guru membuat peserta didik aktif, terutama dalam kegiatan bertanya dan mengungkapkan ide. Hal tersebut tercermin juga dari hasil angket peserta didik yaitu peserta didik jarang bertanya dalam pembelajaran dan tidak berani dalam mengungkapkan pendapat.

Berdasarkan permasalahan tersebut, dapat disimpulkan bahwa peserta didik mengalami permasalahan dalam ranah 
keterampilan. Permasalahan utama berada pada indikator keterampilan presentasi yaitu peserta didik tidak berani dalam mengungkapkan pendapat dan tidak berani dalam bertanya (permasalahan dalam membuat peserta didik aktif). Selain itu, guru juga sulit untuk membuat peserta didik aktif. Aktivitas peserta didik terutama dalam bertanya dan mengungkapkan ide dapat diasah melalui kegitan belajar kooperatif, sedangkan guru belum menerapkan pembelajaran kooperatif. Pembelajaran kooperatif merupakan tuntutan dari kurikulum 2013.

Pada penelitian ini materi yang dipilih adalah KD 3.7 (Interaksi Makhluk Hidup) yang cenderung banyak melakukan observasi, sedangkan untuk kegiatan observasi sulit dilakukan selama proses pembelajaran, yaitu sulit untuk mengefisienkan waktu dan mengontrol kegiatan di luar kelas, sehingga dibutuhkan alternatif solusi untuk menghadirkan pengamatan tersebut melalui contoh-contoh gambar.

Bila model pembelajaran diganti sebagai solusi permasalahan pembelajaran, maka akan memakan waktu adaptasi yang cukup lama untuk peserta didik dalam menyesuaikan model pembelajaran. Selain itu, pendekatan yang digunakan di sekolah juga telah menggunakan pendekatan saintifik yang merupakan pendekatan yang harus dilaksakan oleh guru dalam pembelajaran, keharusan tersebut tertuang dalam Permendikbud No. 103 tahun 2014, sehingga hanya metode yang dapat divariasikan untuk mengatasi permasalahn peserta didik.

Mengingat permasalahan yang dihadapi peserta didik dan guru di kelas dalam menerapkan kurikulum 2013 dalam proses pembelajaran, maka dibutuhkan alternatif solusi metode pembelajaran yang memuat pembelajaran dengan menggunakan media gambar, pembelajaran kooperatif dan dapat membuat peserta didik aktif. Bila permasalahan tidak diatasi maka akan berdampak negatif pada kompetensi peserta didik.
Berdasarkan pertimbangan permasalahan yang dialami peserta didik, tuntutan kurikulum 2013 dan materi pembelajaran, maka peneliti mengajukan alternatif solusi yaitu metode example non example. Menurut Hosnan (2014: 256) metode example non example masuk ke dalam pembelajaran kooperatif. Metode example non example merupakan metode pembelajaran yang menggunakan gambar sebagai media penyampaian materi pelajaran dan lebih menekankan kegiatan analisis gambar. Melalui metode ini peserta didik didorong belajar berpikir kritis melalui permasalahan yang termuat dalam gambar-gambar. Berdasarkan hasil penelitian terdahulu, oleh Amrianto \& Lufri (2019) menyatakan bahwa metode example non example cocok untuk dikolaborasikan dengan model discovery learning dan saat ini pada kelas peneliti, guru telah terbiasa menerapkan model discovery learning di kelas tersebut, sehingga peneliti hanya meneruskan model yang digunakan guru di sekolah.

Selain itu, pertimbangan pemilihan metode example non example yaitu meteode ini efektif dalam meningkatkan aktivitas peserta didik dalam pembelajaran (Setyaningsih, Margereta, \& Bambang, 2013); (Suryani, Rusdi, \& Syafri, 2016). Menurut Hosnan (2014), salah satu kelebihan metode example non example yaitu memberikan kesempatan kepada peserta didik dalam mengemukakan pendapat. Mengemukakan pendapat merupakan salah satu indikator dalam keterampilan presentasi, hal ini sesuai dengan permasalahan peserta didik yang tidak berani dalam mengemukakan pendapat. Selain itu melalui gambar-gambar yang menarik, peserta didik akan termotivasi dalam belajar dan bertanya (Nurjannah, 2018). Motivasi yang tinggi mempengaruhi aktivitas peserta didik (Suryabrata, 2008). Bertanya juga meruapakan salah satu indikator dalam keterampilan presentasi. Melalui kegiatan menganalisis contoh, peserta didik dapat difasilitasi untuk belajar 
membuktikan suatu (Knuth, E., Orit, Z., Amy., 2017).

Melalui pelaksanaan metode example non example diharapkan mampu memberikan pengaruh positif terhadap kompetensi peserta didik, serta memberikan suasana berbeda serta menyenangkan dalam pembelajaran. Suasana pembelajaran yang berbeda akan menarik perhatian peserta didik dalam memahami pembelajaran (Lufri, Fitri, \& Yogica, 2018).

\section{METODE PENELITIAN}

Jenis penelitian adalah kuantitatif dengan desain eksperimen-semu (quasi-experimental design). Penelitian ini dilakukan di tahun 2019 pada semester II kelas VII Tahun Pelajaran 2018/2019 SMP Negeri 18 Padang. Populasi penelitian yaitu seluruh peserta didik kelas VII SMP Negeri 18 Padang tahun pelajaran 2018/2019 yang berjumlah 228 dari 9 kelas. Sampel penelitian yaitu kelas yang diajarkan oleh guru yang sama dan kedua kelas tersebut memiliki nilai varian yang sama (supaya pengaruh perlakuan dapat terlihat jelas).

Pada proses pembelajaran, guru memiliki strategi yang berbeda, sehingga penelitian dilakukan pada kelas yang memiliki guru sama, untuk menyamakan pengalaman awal peserta didik dalam proses pembelajaran. Peneliti melakukan penelitian di kelas VII.6 dan VII.8. Selanjutnya untuk kriteria kedua yaitu dengan nilai varian yang sama. Peneliti melakukan uji homogenitas varian terhadap nilai UH dari dua kelas untuk melihat apakah nilai varian antara dua kelas tersebut sama atau tidak. Hasil yang didapatkan bahwa nilai signifikansi ke dua kelas tersebut adalah 0.120 , yang menandakan bahwa ke dua kelas memiliki varian yang sama.

Penentuan kelas kontrol dan eksperimen dalam sampel penelitian menggunakan cara pengundian. Berdasarkan hasil pengundian, maka didapatkan bahwa kelas VII.6 sebagai kelas kontrol dengan 31 peserta didik dan kelas VII.8 sebagai kelas eksperimen dengan 32 peserta didik. Desain penelitian menggunakan Randomized Control-Group Posttest Only Design.

Instrumen penelitian menggunakan lembar pengamatan praktikum dan projek. Lembar pengamatan praktikum dan projek dilengkapi dengan rubrik penilaian untuk mempermudah dalam pemberian nilai bagi peserta didik. Lembar pengamatan juga divalidasi oleh satu dosen ahli dan satu guru IPA.

Pelaksanaan penelitian dilakukan dengan perlakuan dengan memberikan metode example non example pada kelas ekperimen. Metode example non example dilaksanakan dalam model discovery learning dengan pendekatan saintifik.

Pengolahan data menggunakan aplikasi SPSS. Teknik analisis data dengan melakukan uji hipotesis. Uji statistik yang digunakan untuk uji hipotesisi menggunakan uji nonparametrik (uji Mann-Whitney UTest). Uji nonparametrik dipilih karena berdasarkan uji prasyarat didapatkan bahwa data tidak homogen dan tidak terdistribusi normal (sig. <0.05).

\section{HASIL DAN PEMBAHASAN}

Data penelitian kompetensi keterampilan didapatkan dari pengamatan yang dilakukan oleh satu guru bidang studi dan satu teman sebagai observer. Data penelitian kompetensi ranah psikomotor dapat dilihat pada Tabel 1 .

Tabel 1. Nilai Keterampilan Peserta Didik

\begin{tabular}{|l|c|c|c|c|}
\hline \multicolumn{1}{|c|}{ Kelas } & $\mathrm{N}$ & $\begin{array}{c}\text { Rata- } \\
\text { rata }\end{array}$ & $\mathrm{X}_{\max }$ & $\mathrm{X}_{\min }$ \\
\hline Eksperimen & 32 & 87.03 & 90 & 83 \\
\hline Kontrol & 31 & 83.95 & 90 & 78 \\
\hline
\end{tabular}

Uji hipotesis dilakukan dengan menggunakan SPSS. Hasil uji hipotesis dapat dilihat pada Tabel 2.

Tabel 2. Hasil Perhitungan Hipotesis

\begin{tabular}{|c|c|c|c|}
\hline Kelas & Sig. & A & Kesimpulan \\
\cline { 1 - 3 } Eksperimen & 0.034 & 0.05 & $\mathrm{H}_{0}$ ditolak \\
\cline { 1 - 1 } Kontrol & 0.034 & \\
\hline
\end{tabular}


Berdasarkan hasil penelitian bahwa ratarata nilai kompetensi keterampilan kelas eksperimen (87.03) lebih tinggi dibandingkan nilai rata-rata kelas kontrol (83.95). Uji hipotesis nilai signifikansi ranah keterampilan adalah 0.034 yang menandakan bahwa pembelajaran metode example non example berpengaruh terhadap kompetensi peserta didik ranah keterampilan.

Pada ranah keterampilan terutama saat pelaksanaan praktikum, peserta didik sangat antusias terutama dalam bertanya tentang benda-benda yang aktual yang mereka lihat selama praktikum berlangsung. Oleh sebab itu dalam pembelajaran praktikum, dengan adanya data atau pengamatan langsung sangat mendukung keterlaksaaan pembelajaran, terutama pada kegiatan mengamati yang akan mendukung adanya kegiatan bertanya dalam pembelajaran. Mengamati objek langsung membuat peserta didik lebih aktif dan kritis dalam mengemukanan pertanyaan, karena rasa ingin tahu peserta didik bertambah dengan adanya objek-objek yang faktual yang belum pernah mereka lihat sebelumnya selama pembelajaran.

Pengamatan langsung sebagai hasil pengamatan juga merupakan salah satu bentuk pengaplikasian metode example non example, karena hasil pengamatan merupakan data yang dapat dianalisis. Metode example non example bukan hanya terbatas pada gambar saja, melainkan bisa berupa hasil pengamatan yang lebih bersifat visualisasi (dapat diamati) dapat dijadikan bahan dalam pelaksanaan metode example non example.

Pada pelaksanaan praktikum, peserta didik dihadapkan pada data berbentuk gambar dan tabel yang peserta didik amati selama proses praktikum. Hasil pengamatan mendukung pemahaman peserta didik, yaitu mengkonkretkan narasi/materi yang telah dipelajari peserta didik (Takacs \& Adriana, 2017). Selain itu melalui gambar dan hasil pengamatan peserta didik, maka peserta didik terfasilitasi dalam malakukan kegiatan proses discovery (penemuan) (Huda, 2014).
Pengetahuan yang ditemukan sendiri oleh peserta didik akan bertahan lama dalam ingatan (Dipuja, Lufri, \& Ahda, 2018).

Sesuai dengan tuntutan metode yang lebih pada kegiatan analisis, jadi untuk LKPD peserta didik dilengkapi dengan pernyataan (analisis) peserta didik tentang hasil pengamatan (hasil praktikum yang dilakukan). LKDP yang diberikan item analisis gambar memiliki hasil yang positif, yaitu mampu memacu dan memotivasi peserta didik untuk bertanya terhadap apa yang mereka buat (yang diamati). Dengan kata lain mendukung adanya kegiatan bertanya. Selain itu juga dapat menghidupkan suasana diskusi karena peserta didik aktif untuk bertanya, sehingga pembelajaran aktif dapat terlaksana dengan baik. Kegiatan diskusi merujuk pada kegiatan menemukan persamaan-persamaan, yang nantinya akan menambah keyakinan peserta didik akan suatu ilmu pengetahuan (Mufit, Festiyed, Fauzan, \& Lufri, 2018). Melalui kegiatan diskusi, peserta didik dapat memperkuat dan memperluas pengetahuan yang telah dipelajari (Alberida, Lufri, Festiyed, \& Barlian, 2018).

Item analisis hasil pengamatan juga memberikan bekal awal dan kepercayaan diri dari peserta didik untuk tampil dalam presentasi kelas, bekal awal yang dimaksudkan di sini adalah hasil analisis pengamatan. Hal tersebut terlihat saat guru memberikan kesempatan kelompok untuk tampil, peserta didik berebutan untuk tampil pertama, karena mereka telah memiliki bekal awal untuk tampil.

Disisi lain, dengan adanya metode example non example sebagai salah satu pembelajaran koperatif, juga memberikan kontribusi, yaitu melalui kegiatan kelompok peserta didik lebih luas dan lebih banyak ide jawaban yang bisa dijabarkan dalam item analisis hasil pengamatan. Selain itu peserta didik juga tidak terbebani saat akan tampil persentasi, karena mereka tampil bersamasama dan bila hasil pembahasan salah, maka tidak ada satu peserta didik yang merasa bersalah, berbeda saat tampil sendiri 
cenderung peserta didik takut kalau nanti salah dan disoraki oleh teman-temannya yang ada di kelas.

Melalui pelaksanaan langkah-langkah metode example non example, peserta didik diberikan kesempatan untuk berdiskusi antar anggota kelompok dan mempresentasikan hasil diskusi. Hal tesebut dapat mengasah mental dan kepercayaan peserta didik dalam menyampaikan pendapat di depan orang banyak.

Kompetensi yang sangat diasah dalam penerapan metode example non example adalah dalam kompetensi keterampilan presentasi. Peserta didik diberikan kesempatan dalam mendiskusikan dan memverifikasi hasil pengamatan yang dilakukan. Meningkatnya penguasaan keterampilan presentasi peserta didik, juga ikut mendukung keberhasilan pelaksanaan pembelajaran yaitu terkait kegiatan bertanya dan berdiskusi dalam pembelajaran. Meningkatnya kompetensi presentasi peserta didik, maka juga meningkatkan kompetensi keterampilan peserta didik dalam kelas. Sama halnya dengan penelitian Amrianto \& Lufri (2019) menerangkan bahwa metode example non example mampu meningkatkan kompetensi keterampilan peserta didik.

\section{KESIMPULAN DAN REKOMENDASI}

Kesimpulan pada penelitian ini yaitu metode example non example berpengaruh terhadap kompetensi IPA peserta didik kelas VII SMP Negeri 18 Padang.

Kompetensi peserta didik dari ranah psikomotor mengalami peningkatan dengan adanya perlakuan, selain itu juga dapat mendukung terciptanya pembelajaran aktif. Kegiatan kelompok dapat memberikan kesempatan kepada peserta didik lebih luas menggali pengetahuan, karena ide-ide yang dikemukakan lebih banyak.

Berdasarkan kesimpulan yang telah diuraikan sebelumnya, diperoleh temuan yang dapat dijadikan rekomendasi bagi guru, agar dapat menggunakan metode metode example non example sebagai upaya meningkatkan kompetensi psikomotor IPA peserta didik di sekolah.

\section{REFERENSI}

Alberida, H., Lufri, Festiyed, \& Barlian, E. (2018). Problem Solving Model for Science Learning. In IOP Conference Series: Materials Science and Engineering, 335(1), 012094.

Amrianto, \& Lufri. (2019). Effect of Example Non Example Method Implementation in Scientific Approach and Discovery Learning Model on VII Garde Students' Psychomotor Competence in Learning Natural Science. International Journl of Progressive Science and Technologies (IJPSAT), 2(13), 211-215.

Dipuja, D. A., Lufri, \& Ahda, Y. (2018). Development Biology Worksheet Oriented Accelerated Learning on Plantae and Ecosystems for 10th-Grade Senior High School Students". In IOP Conference Series: Materials Science and Engineering, 335(1), 012094.

Hosnan. (2014). Pendekatan dan Kontekstual dalam Pembelajaran Abad 21. Jakarta: Ghalia Indonesia.

Huda, H. (2014). Model-model Pengajaran dan Pembelajaran. Yogyakarta: Pusta Pelajar.

Kemendikbud. (2013). Permendikbud Republik Indonesia Nomor 68 Tahun 2013. Jakarta: Kemendikbud.

Kemendikbud. (2018). Data Sekolah Kemendikbud Tahun Pelajaran 2017/2018. Retrieved from http://sekolah.data.kemdikbud.go.id/ind ex.php/chome/pencarian/ (Accessed 27 Februari 2018).

Knuth, E., Orit, Z., Amy., E. (2017). The Role and Use of Examples in Learning to Prove. Elsevier: Journal of Mathematical Behavior, 1-7.

Lufri, Fitri, R., \& Yogica, R. (2018). Development of Learning Models Based on Problem Solving and Meaningful Learning Standards by 
Expert Validity for Animal Development Course. In IOP Conference Series: Materials Science and Engineering, 335(1), 012094.

Mufit, F., Festiyed, F., Fauzan, A., \& Lufri. (2018). Impact of Learning Model Based on Cognitive Conflict toward Student's Conceptual Understanding. In IOP Conference Series: Materials Science and Engineering, 335(1), 012094.

Nurjannah. (2018). Pengaruh Media Gambar terhadap Motivasi Belajar Pelajaran Bahasa Indonesia Kelas III SDN Pasi Pinang Kecamatan Meureubo Kabupaten Acah Barat. Bina Gogik, 5(1), 71-78.

Setyaningsih, Y., Margereta, R., \& Bambang, P. (2013). Penerapan Metode Example Non Example dalam
Pembelajaran Keanekaragaman Hewan di SMPN 2 Tengaran Kabupaten Semarang. Journal of Biology Education, 2(2), 156-164.

Suryabrata, S. (2008). Psikologi Pendidikan. Jakarta: RajaGrafindo Persada.

Suryani, K., Rusdi, \& Syafri, M. (2016). Penerapan Metode Examples Non Examples untuk Meningkatkan Akivitas dan Hasil Belajar Matematika Siswa Kelas VII SMP Al-Karim Kota Bengkulu (masters). Universitas Bengkulu.

Takacs, Z. K., \& Adriana, G. B. (2017). How Pictures in Picture Storybooks Support Young Children's Story Comprehension: An Eye-Tracking Experiment. Elsevier: Journal of Experimental Child Psychology, 174, $1-12$.

\section{Article Metadata:}

Lufri. Amrianto. Anhar, A. (2019). The Effect of Example Non Example Method on Students' Natural Science Competence on Living Creatures Interaction Material. Ta'dib, 22 (2), 99-104.

http://dx.doi.org/10.31958/jt.v22i2.1506

Keywords: Example Non Example method, Competence, Motoric Skills

Coresponding author: Amrianto, Universitas Negeri Padang, amrianto20@ gmail.com 